\title{
Duygusal Emeğin İş-Aile Çatışması Üzerine Etkisi: İzmir Şehir Otelleri Örneği ${ }^{1}$
}

The Relationship Between Emotional Labor and Work-Family Conflict among Hotel Employees in İzmir City Hotels

\author{
Tuğba PALA*, Mustafa TEPECi**, Alp TiMUR*** \\ *Dr., Mersin Üniversitesi, Turizm Fakültesi, Çiftlikköy Kampüsü, 33343, Yenişehir, Mersin. \\ E-posta: tugbapala82@gmail.com \\ ORCID: 0000-0001-8346-9901 \\ **Prof. Dr., Celal Bayar Üniversitesi, İşletme Fakültesi, Turizm İşletmeciliği Bölümü, Muradiye Yerleşkesi, 45140, Manisa. \\ E-posta: mustafa.tepeci@cbu.edu.tr \\ ORCID: 0000-0001-9311-1532 \\ ***Prof. Dr., Dokuz Eylül Üniversitesi, ìktisadi İdari Bilimler Fakültesi, ìktisat Bölümü, Dokuzçeşmeler Kampüsü, 35160, Buca, İzmir. \\ E-posta: alp.timur@deu.edu.tr \\ ORCID: 0000-0003-4386-1145
}

\section{MAKALE BILGILERI}

Makale ișlem bilgileri:

Gönderilme tarihi: 22 Temmuz 2016

Düzeltme: 3 Ekim 2016

Düzeltme: 27 Ekim 2016

Kabul: 27 Kasım 2016

Anahtar sözcükler: İş-aile çatışması, Duygusal emek, Yüzeysel davranıs,, Otel çalışanları.

\section{ARTICLE INFO}

Article history:

Submitted: 22 July 2016

Resubmitted: 3 October 2016

Resubmitted: 27 October 2016

Accepted: 27 November 2016

Key words: Work-family conflict, Emotional labor, Surface acting, Hotel employees.

\section{ÖZ}

Bu çalıșmada duygusal emek ile iş-aile çatıșması arasındaki ilişkinin ortaya çıkarılması amaçlanmıștır. Bu doğrultuda İzmir ilinde bulunan on otelde; 3, 4, 5 yıldızlı ve butik otel çalışanlarından toplanan 302 anketin verileri analizlere tabi tutulmuştur. Analizler sonucunda yüzeysel ve samimi davranış ile zaman temelli iş-aile catıșması; yüzeysel ve derin davranıs ile davranıs temelli iș-aile çatıșması arasında pozitif bir iliși bulunmustur. Samimi davranıs sergileyen otel çalışanları daha fazla zaman temelli iș-aile çatışması; derin davranıș sergileyen çalışanlar daha fazla davranış temelli iş-aile çatışması yaşarken yüzeysel davranış sergileyenler hem zaman hem de davranış temelli iş-aile çatışmasını daha fazla yaşamaktadır. Ayrıca regresyon analizinde yüzeysel davranışın zaman temelli iş-aile çatışması ve davranış temelli iş-aile çatışmasının önceli olduğu ve bu iki değişkeni açıkladığı görülmektedir.

\section{ABSTRACT}

The purpose of the study is to determine the relationship between emotional labor and work-family conflict. The data were collected from $\mathbf{3 0 2}$ hotel employees working in ten hotels, which are classified as boutique and three to five star hotels in İzmir.The analyses indicate that surface and genuine acting are positively related with time-based work-family conflict; surface and deep acting are positively related with behavioral-based work-family conflict. Employees displaying genuine acting experience time-based work-family conflict and employees displaying deep acting experience behavioral-based work-family conflict. Employees who display surface acting experience both time-based and behavioral-based work-family conflicts. The regression analysis indicates that surface acting explains both time-based and behavioral-based work-family conflicts.

\section{Giriş}

Turizm sektöründe müşteri memnuniyeti, önemli ölçüde çalışanın verdiği hizmetin kalitesi ile sağlanmaktadır. Kaliteli hizmetin müşteriye su-

\footnotetext{
${ }^{1}$ Bu makale,Tuğba Pala Morkoç'un Dokuz Eylül Üniversitesi Sosyal Bilimler Enstitüsü'nde yazılan "Otel Çalışanlarında Duygusal Emek ve İş-Aile Çatışması İlişkisi: İzmir Şehir Oteller Örneği" başlıklı doktora tezinden derlenmiştir.
}

nulması, çalışan ile müşteri arasındaki iletişimin niteliğine bağlıdır. Bu iletişimde çalışanlar duygularını düzenleyerek müşterilere güler yüz gösterme ve nazik olmakta ya da bazı olumsuz duygularını gizleyerek işletmelerinin istediği şekilde davranmaktadırlar. İletişimsel bir icra olan duygusal emeğin müşteriye yansıtılma şekli, hizmet sunumunda büyük önem taşımaktadır (Chu ve Murmann 2006). 
Kaliteli hizmetin müşteriye sunulmasının önemi bilinmesine rağmen, uzun çalışma saatleri, ağır iş yükü, rol stresi, sınırlı tatiller, düşük ücret, işgücü devri turizm sektörünün genel problemleri arasında yer almaktadır.Bu gibi problemlerden dolayı turizm sektöründe çalışanlar iş-aile çatışması ileyoğun olarak karşı karşıya gelmektedir (Zhao vd. 2014). İş-aile çatışması, iş stresini ve işte gerilimi (Zhao vd. 2014), duygusal tükenme ve işi bırakma niyetini artırmakta (Yavaş vd. 2008); aynı zamanda iş ve yaşam doyumunu azaltmaktadır (Magnini 2009). Ayrıca birçok araştırmacının ortaya çıkardığı üzere, işte yaşananlar, çalışanları işten sonra da etkilemeye devam etmektedir (Eby vd. 2010). İşteki sıkıntıları eve yansıtan ve iş dişı yaşamında da zorlukları yaşayan çalışanların iş ve yaşam memnuniyetleriile verimlilikleri düşmekte bu süreç devamlı kendini tekrarlamaktadir.

Yönetim ve psikoloji alanında iş-aile çatışmasının bireysel, iş ortamı ve aile boyutunda belirleyicileri üzerinde yapılan çalışmalar (Örneğin, Byron2005; Allen ve Finkelstein 2014; Selvarajan vd. 2016) olmasına rağmen turizmalanyazınında, iş-aile çatışmasının neden kaynaklandığını araştıran çalışmalara çok az rastlanmaktadır (Karatepe vd. 2010). Karatepe vd. (2010) Ankara'da üç yıldız ve yukarısı 54 otelde müşterilerle yüz yüze iletişimde bulunan 620 çalışandan toplanan verilerle yaptığ 1 analizde, iş yükünün çalışanların iş-aile çatışması yaşamalarını artırdığını bulmuştur.

Turizm endüstrisinin iş özellikleri, çalışanların iş ve aile yaşamları arasında çatışma yaşamalarına yol açabilmekte; bu da çalışanların işte gerilim ve stres yaşamasına neden olabilmektedir (Zhao vd. 2014).

Mevcut alanyazın, duygusal emek ve iş-aile çatışması arasındaki ilişkiyi incelerken bu ilişkide değişkenlerin birbirilerini etkileyip etkilemediklerini ve bu etkinin hangi yöne doğru olduğunu araştırmaktadır. Bu doğrultuda yapılan çalışmalar (Montgomery vd. 2005, 2006; Seery vd. 2008; Cheung ve Tang 2009; Yanchus vd. 2010), genellikle duygusal emeğin iş-aile çatışmasını etkilediği yönündedir. Bu çalışmalarda duygusal emek, genelde yüzeysel davranış ve derin davranış olarak operasyonel hale getirilmiş ve sadece yüzeysel davranışın iş-aile çatışması üzerinde etkisi bulunmuştur. Elde edilen bu sonuçlar "psikolog, işletme ve pazarlama çalışanları, doktor, hemşire, çocuk bakıcıları ve devlet memurları" örneklemlerinden toplanan verilerin analizlerinden elde edilmiştir.Çalışan duyguları ve duygusal emek, turizm işletmeleri çalışanlarının önemli bir parçası olmasına rağmen duygu-ilişkili faktörlerin iş-aile çatışması üzerinde etkileri hakkında fazla bir şey bilinmemektedir. Bu nedenle, bu çalışmanın amacı otel işletmelerinde duygusal emek ile iş-aile çatışması arasındaki ilişkiyi belirlemektir.

Müşterilerle yüz yüze ilişkilerin ve iş-aile çatışmasının yoğun yaşanıldığı otel işletmeleri çalışanlarıyla yapılacak araştırma sonuçları, duygusal emek ile iş-aile çatışması arasındaki ilişkiyi daha somut ve geniş bir perspektifte açıklığa kavuşturabilecektir. Burada elde edilen bilgiler ışığındaişletmeler yönetim ve insan kaynakları yönetimi uygulamalarında tercihlerde bulunarak çalışan ve müşteri memnuniyetini sağlayıp, rekabet gücünü arttırabileceklerdir.

\section{ALANYAZIN TARAMASI}

\section{Duygusal Emek}

Turizm işletmelerinde çalışanlar duygusal emeği yaygin olarak göstermektedirler. Çalışanlar aşır1 yorucu ve yoğun iş ortamlarında sabırsız, aşırı talepkâr ve devamlı şikâyet eden müşterilerle çalışırlarken bile arkadaşça, nazik ve yardımsever tavır ve davranışlar takınma durumundadırlar. Duygusal emek kavramı ilk olarak Hochschild (1983) tarafından alanyazına kazandırılmış; Hochschild duygusal emeği, "hizmetin sahne, çalışanların aktör, müşterilerin de izleyici olarak görüldüğü bir sahne" olarak nitelendirerek "herkesin görebildiği, mimik ve jestleri örgütün istediği şekilde gösterebilmek için duyguların yönetilmesi; ücretle satılan bu nedenle de değiştirilebilen bir değer" olarak tanımlamıştır.

Ashforth ve Humphrey (1993), bir hizmet karşılaşması boyunca örgüt tarafından istenilen duyguların yansıtılmasını duygusal emek olarak tanımlamışlardır. Hochschild'den farklı olarak gözlenebilen davranışlar üzerinde durmuşlar, davranışların altında yatan gözlenemeyen duy- 
guların ne olduğu ile pek fazla ilgilenmemişlerdir. Bunun nedeni, hizmet kalitesinin çalışanın gözlenen davranışları ile değerlendirilebileceğini düşünmeleridir.

Hochschild (1983) duygusal emeği, yüzeysel (örgütün gösterilmesini istediği duyguları gerçekten hissetmeyip yalnızca mimik ve jestleri kullanarak sergilemek) ve derin davranış (örgütün gösterilmesini istediği duyguları içsel duygularını değiştirerek sergilemek) olarak iki boyutlu bir yapıda kavramsallaştırırken Ashforth ve Humphrey (1993) bu boyutlar üzerine samimi davranışı da (örgütün gösterilmesini istediği duygular ile çalışanın gerçek duygularının aynı olması) ekleyerek duygusal emeği; yüzeysel, derin ve samimi davranı̧̧ olarak üç boyutta ele almaktadır.

Diefendorff vd. (2005), Ashforth ve Humphrey (1993) ile benzer şekilde samimi davranışında içinde bulunduğu duygusal emeğin üç boyutlu bir kavram olduğunu ileri sürmüştür. Kruml ve Geddes (2000) duygusal emeği, duygusal uyumsuzluk ve duygusal çaba olarak iki boyutta değerlendirmiştir. Lee ve Ok (2012) ise Kruml ve Geddes'in (2000) duygusal çaba ve duygusal uyumsuzluk boyutlarının yüzeysel, derin ve samimi davranışı kapsadığını söyleyerek duygusal uyumsuzluğun yüzeysel davranıştan, duygusal çabanın ise derin ve samimi davranıştan oluştuğunu belirtmiştir. İş-aile yaşam çatışması ile duygusal emek arasındaki ilişkinin incelendiği çalışmalarda (Montgomery vd. 2005, 2006; Seery vd. 2008; Cheung ve Tang 2009; Yanchus vd. 2010) genelde yüzeysel ve derin davranış şeklinde boyutlarla duygusal emek kavramı araştırılmıştır.

Chu ve Murrmann (2006), Kruml ve Geddes' in (2000) duygusal emek ölçeğini kullanarak 19 maddeden ve iki boyuttan oluşan Konaklama İşletmeleri Duygusal Emek Ölçeği geliştirmişlerdir. Bu boyutlar, duygusal çaba ve duygusal uyumsuzluk olarak adlandırılmıştır. Duygusal çaba boyutu, derin davranış ile ilgili ölçek maddelerinden oluşurken duygusal uyumsuzluk boyutu samimi davranış ve yüzeysel davranış ile ilgili ölçek maddelerinin bir araya geldiği boyuttur. Daha sonra Chu ve Murrmann tarafindan geliştirilen duygusal emek ölçeğini Pala ve Tepeci $(2009 ; 2014)$ Türkçeye adapte etmiştir.
Duygusal emek ile ilgili çalışmalar yapan araştırmacılar, duygusal emeğin sonuçları ile ilgili farklı fikirler ileri sürmektedir. Bazı araştırmacılar, duygusal emeğin olumsuz sonuçlar doğuracağını ileri sürerken bazıları ise olumlu sonuçlarının da olacağı kanısındadır. Hochschild'in (1983) çalışanın örgütün göstermesini istediği duyguları ifade etmek zorunda olmasından dolayı kendi duyguları üzerindeki kontrolü yitiriyor olması hissinin, çalışanda olumsuz duygular yaratacağ 1 görüşünü ileri sürmesinden bu yana birçok araştırmacı duygusal emeğin olumsuz sonuçları ile ilgilenmektedir. Duygusal emeğin olumsuz sonuçları ile ilgilenen araştırmacılar genellikle tükenmişlik ve iş tatminsizliği ile ilişki kurmaktadır (Hochschild 1983; Wharton ve Erickson 1993; Morris ve Feldman 1996; Grandey 2000; Chu vd. 2012). Olumsuz sonuçları ile ilgilenen araştırmacıların büyük bir kısmı da duygusal emeği, özsaygı, rol yabancılaşması, kendine yabancılaşma ve depresyon gibi çalışanın psikolojik refahı ile ilgili kavramlarla ilişkilendirmektedir (Ashforth ve Humphrey 1993; Wharton ve Erickson 1993). Buna karşın bazı araştırmalar duygusal emeğin finansal kazanç, güven duygusu, özsaygı, öz yeterlilik ve iş tatmini artışı gibi olumlu sonuçlar doğuracağını ileri sürmektedir (Ashforth ve Humphrey 1993; Wharton ve Erickson 1993; Pala ve Tepeci 2014). Lee ve Ok (2015) otel çalışanlarının duygusal emek gösterimlerinin onların hizmet oryantasyonlarının artmasına (müşteri yönlü olmalarına) katkı sağladığını belirlemiştir.

\section{İş-Aile Çatış̧ması}

Greenhaus ve Beutell (1985) iş-aile çatışmasını "iş ve aile rollerinin birbiriyle karşılıklı olarak uyuşmamasından kaynaklanan baskıdan dolayı bir role katılımın diğer role katılımı güçleştirdiği durum" olarak tanımlamıştır. İ̧s-aile yaşam çatışmasının temel olarak üç çeşidi bulunmaktadır. Bunlar; zaman, sıkıntı ve davranış temelli çatışmalardır. Zaman temelli iş-aile çatışması; zaman, bireyin istekleri doğrultusunda her iki yaşam alanına da dağıtılamadığında yaşanan çatışma türüdür. Sıkıntı temelli iş-aile çatışması; bir roldeki baskının (sıkıntının) diğer rolün icrasını etkilemesidir. Davranış temelli çatışma ise rol davra- 
nışındaki belirli örneklerin diğer rolden beklenen davranışlarla uyumlu olmadığı durumda ortaya çıkmasıdır (Greenhaus ve Beutell 1985).

Ayrıca iş-aile çatışması iki yönlü olarak ortaya çıkmaktadır. Bunlar; iş-aile çatışması olarak bilinen iş alanının aile alanına müdahalesi ve aile-iş yaşam çatışması olarak bilinen aile alanının iş alanına müdahalesidir (Frone 2003). İş-aile yaşam çatışması ve aile-iş yaşam çatışması yönlerinin de farklı öncelleri ve sonuçları olduğu için, bu yönleri farklı kavramlar olarak ele alınabilir. İş-aile yaşam çatışması; iş taleplerinin aile sorumluluklarının yerine getirilmesini zorlaştırması iken aile-iş yaşam çatışması; aile taleplerinin iş ile ilgili görevlerin yapılmasını kısıtlamasıdır. İşin aile yaşam alanına müdahalesi ve ailenin iş yaşam alanına müdahalesi birbiri ile ilişkili ancak birbirinden farklı süreçlerdir (Voydanoff 2004).

İş-aile çatışması çeşitli yollarla ölçülmeye çalışılmıştır ancak bu çalışmalar genellikle iş-aile çatışmasının iki yönlü olduğunu göz ardı etmiştir (Carlson vd. 2000). Bu durumdan yola çıkarak Carlson vd. iki yönlü ve her iki yönde de iş-aile çatışmasının üç türünü dahil eden altı boyutlu bir ölçek geliştirmiştir. İş-aile çatışması ölçeğinde her boyutunda üç ölçek maddesi (zaman temelli, sıkıntı temelli, davranış temelli), bulunmak üzere dokuz maddelik bir ölçek kullanmıştır. Carlson vd. (2000) tarafından geliştirilen ölçek, alanyazında yaygın olarak kullanilmakta (Seery vd. 2008; Yanchus vd. 2010) ve yukarıda bahsedilen zaman, sıkıntı ve davranış boyutlarıyla iş-aile çatışmasını güvenilir ve geçerli şekilde ölçmektedir. Carlsonvd.'nin geliştirdiği iş-aile çatışması ölçeği, Greenhaus ve Beutell (1985) tarafından kavramlaştırılan işaile çatışmasının üç boyutunu da ölçmektedir. Ölçeğin her bir boyutunun bireysel ve örgütsel çıktılarla farklı şekilde ilişki içerisinde olabildiği ve her bir boyutun farklı etkileri olmasından dolayı daha etkili önleme ve sorun çözme imkânı sağlayabileceği görülmektedir (Seery vd. 2008).

\section{Duygusal Emek ve İş-Aile Çatışması İlişkisi}

Son yıllarda, duygusal emeği iş-aile çatışmasınin önceli (Montgomery vd. 2005, 2006; Seery vd.
2008; Cheung ve Tang 2009; Yanchus vd. 2010) olarak ele alan çalışmalar görülmektedir. Duygusal emek boyutlarının iş-aile çatışmasının önceli olarak ele alınmasının nedeni, duygusal emeğin hizmet sektöründe yoğun olarak yaşanması ve çalışanlar üzerinde stres ve tükenmişlik gibi etkilerinin görülebilmesidir (Brotheridge ve Lee 2002; Cheung ve Tang 2009).

Cheung ve Tang (2009) duygusal emek ile işaile çatışması arasındaki ilişkinin kavramsal olarak açıklanmasında Kaynakların Korunması Teorisi'nin yol gösterici olduğunu belirtmektedir. Bu teoriye göre; çalışanlar tehdit edildiklerinde veya değerli kaynaklarını kaybettiklerinde stres oluşur. Stresi azaltmak için bireyler işlerinden elde ettikleri kaynaklarını korumaya ya da arttırmaya çalışarak kayıplarını en aza indirme çabasındadırlar. Çalışanlar iş ve aile rollerinin gereklerini yerine getirmek için değerli kaynakları kullanmak zorundadırlar. İş taleplerini karşılamak için harcadıkları enerji (duygusal emek gibi), sadece kaynakların kaybı değil aynı zamanda aile rollerini yerine getirmek için gerekli olan enerijye de tehdit oluşturmaktadır. Stres yüksek seviyede olduğunda çalışanlar iş ve aile rollerini dengeleyemez ve bu durum iş-aile, aile-iş çatışmasına yol açar.

Yüzeysel davranış çalışanların gerçekten hissetmedikleri duyguları göstermeye çalışmalarını gerektirmekte, kişisel kaynakları azaltmakta ve enerji kaybına yol açarak iş ve aile rollerinin karşılanmasinı engellemektedir (Cheung ve Tang 2009). Derin davranışs sergileme, çalışanların kaynakları kullanmasını gerektirse de çalışanlar, iş tatmini (Grandey 2003) ve kişisel başarı (Brotheridge ve Lee 2002) gibi değerli kaynakları elde edip daha az iş-aile çatışması yaşamaktadır (Cheung ve Tang 2009). Yapılan çalışmalarda, işyerinde gösterilen yüzeysel davranışın iş-aile çatışmasını arttırdığ saptanmıştır (Montgomery vd. 2005,2006; Seery vd.2008; Cheung ve Tang 2009; Yanchus vd. 2010). Derin davranış ile iş-aile çatışması arasında bir ilişki ortaya çıkmamıştır (Montgomery vd. 2006; Seery vd. 2008; Yanchus vd. 2010).

Cheung ve Tang (2009) samimi davranışın sonuçlarını alan araştırması ya da veriye dayalı olarak test etmeyen geçmişteki çalışmaların bir 
boşluğunu tamamlayarak, samimi davranışın da iş-aile çatışması üzerine olan etkisini araştırmıştır. Yüzeysel davranışın aksine (derin davranışın iş-aile çatışması ile negatif ilişkili olduğunu düşünseler de) derin davranış ve doğal duyguların ifadesi ile iş-aile çatışması arasında bir ilişki bulunamamıştır. Bu durumun nedenini, çalışanların derin davranış sergilediklerinde gerçek duygularından fedakârlık etmeden örgütün istediği duyguları göstermeleri ile açıklamışlardır.

Yüzeysel ve derin davranış, çalışanların enerjilerini azaltarak sıkıntı veya gerilime yol açacaktır. Ancak samimi duygular çalışanların kendi gerçek duygularını yansıttığından yüzeysel ve derin davranışın neden olduğu olumsuz etkileri yaratmayacaktır. Başka bir ifadeyle, samimi davranışın iş-aile çatışması ile negatif ilişkili olacağı öngörülmektedir.Bu nedenle çalışanların sergilemiş oldukları yüzeysel veya derin davranış arttığında, yaşamış oldukları iş-aile çatışmasının da artacağ 1 düşünülürken samimi davranış sergileyen çalışanların iş-aile çatışmasını daha az yaşayacağı düşünülmektedir. Bu bilgiler ışı̆̆ında, duygusal emek boyutları ve iş-aile çatışması boyutları arasındaki ilişkiyi araştırmak amacıyla aşağıdaki hipotezler belirlenmiştir.

H1: Yüzeysel davranış, zaman temelli iş-aile çatışması, sıkıntı temelli iş-aile çatışması ve davranış temelli iş-aile çatışması ile pozitif ilişkilidir.

$\mathrm{H}_{2}$ : Derin davranış zaman temelli iş-aile çatışmaSı, sıkıntı temelli iş-aile çatışması ve davranış temelli iş-aile çatışması ile pozitif ilişkilidir.

$\mathrm{H}_{3}$ : Samimi davranış, zaman temelli iş-aile çatışması, sıkıntı temelli iş-aile çatışması ve davranış temelli iş-aile çatışması ile negatif ilişkilidir.

Bu çalışmada duygusal emek boyutlarının her birinin iş-aile çatışması boyutlarının her biri ile farklı ilişki içerisinde olduğu ve duygusal emek boyutlarının iş-aile çatışmasının her bir boyutu üzerinde etkili olduğu düşünülmektedir.

$\mathrm{H}_{4}$ : Duygusal emek boyutlarının zaman temelli işaile çatışması,sıkıntı temelli iş-aile çatışması ve davranış temelli iş-aile çatışması üzerinde etkisi vardir.

\section{YÖNTEM}

\section{Örneklem ve Veri Toplama}

Çalışmanın evrenini İzmir şehir otellerinin tüm çalışanları oluşturmaktadır. Şehir merkezinde bulunan, üç, dört ve beş yıldızlı ve butik şehir otel çalışanlarıyla sınırlandırılan evrende yer alan otellerin sayısı 40 adettir (İzmir İl Kültür ve Turizm Müdürlüğü 2014). Üç ve daha fazla yıld1za sahip olan otellerin ve butik otellerin yöneticileri ile temasa geçilerek bu çalışma ile ilgili destekleri talep edilmiştir, ancak 40 otelden yalnızca 10 tanesi (biri butik, ikisi üç yıldızlı, dördü dört yıldızlı ve üçü ise beş yıldızlı) veri toplama konusunda yardımcı olmuştur. Bu otellerde çalışan sayısı yaklaşık 700 olarak belirlenmiştir. Şubat ve Mart 2014 tarihleri arasında gerçekleştirilen bu araştırmanın anketleri, araştırmaya katılan otellerin insan kaynakları birimlerine, çalışan sayılarına göre anketin içeriği ve doldurulma aşamasında dikkat edilmesi gereken hususları içeren yönerge ile birlikte araştırmacı tarafından bırakılmış daha sonra yine araştırmacı tarafından anketler insan kaynakları biriminden teslim alınmıştır. Araştırmacının anket toplama sürecine dahil olamamasının nedeni; otel yöneticilerinin işin akışını aksatacağı gerekçesi ile araştırmacının sürece dahil olmasına izin vermemesidir.

Otel yöneticilerine verilen 700 anketten 302 tanesi doldurtularak araştırmacılara geri dönüşü yapılmıştır. Böylece çalışma evreninin yaklaşık \%43'ünden veri toplanması mümkün olmuştur. Araştırmacılara pratik kolaylık sağlaması açısından hazırlanan farklı evren büyüklüklerinden alınması gereken örneklem büyüklüklerini hesaplayan Basılı Tablolar (Yazıcıoğlu ve Erdoğan 2004: 49-50) bu çalışmadaki örneklemin evreni temsil etmek için gerekli olan sayıyı aştığını göstermektedir. Tabloda, çalışmadaki evrene en yakın sayı olarak verilen 750 evren büyüklügüünde, örnekleme hatasının 0,5 ve sonuçların $\% 95$ güven aralığında olmasını (0,05 örnekleme hatası içerebileceğini) kabul ediyorsak örneklem büyüklügü en az 254 olmalıdır. Bu çalışmadaki örneklem büyüklüğünün 302 olması evreni temsil ettiğini göstermektedir. 


\section{Veri Toplama Araçları}

Duygusal Emek Ölçeği: Otel çalışanlarının duygusal emek düzeylerini ve boyutlarını ölçmek için, Pala ve Tepeci $(2009 ; 2014)$ tarafından Türkçeye çevrilerek geçerlilik ve güvenilirliği test edilmiş olan Chu ve Murrmann'ın (2006) Konaklama İşletmeleri Duygusal Emek Ölçeği kullanılmıştır. Pala ve Tepeci tarafından Türkçeye uyarlanan ölçek, Ashforth ve Humphrey'in (1993) kavramsallaştırdığı duygusal emeği yüzeysel, derin ve samimi davranış boyutlarıyla ölçmektedir.

İş-Aile Çatışması Ölçeği: Carlsonvd.'nin (2000) geliştirmiş olduğu iş-aile çatışması ölçeği, işten kaynaklı iş-aile çatışmasının yönünü ve üç türünü (zaman, sıkıntı ve davranış temelli) ölçmektedir. İş-aile çatışması ölçeği, üç boyuttan oluşan her üç boyutun bünyesinde üç madde barındırdığı dokuz maddelik bir ölçektir. Ölçeğin Türkçe alanyazında uyarlaması bulunmadığından, ölçek maddeleri bu çalışma ile Türkçeye çevrilmiştir. Ölçek maddelerinin Türkçeye çevrilme işlemi, turizm sektöründe uzman İngilizce ve Türkçe dillerine hakim üç akademisyen tarafından gerçekleştirilmiştir. Çeviri işlemi yapılırken iki akademisyen tarafından Türkçeye çevrilen ölçek, anlam kayıpları yaşanabileceğinden bir akademisyen tarafından geri çeviri tekniğine başvurularak (Brislin vd. 1973) yeniden İngilizceye çevrilmiştir. İngilizceye çevrilen ölçek maddelerinin anlam kaybına uğrayıp uğramadığına bakılmış, anlam kaybına uğrayan ölçek maddeleri tespit edilerek, anlamının korunacağ 1 şekilde tekrar Türkçeye çevrilmiştir. Örneklemden seçilen 12 kişilik bir gruba uygulanarak maddeler daha açık bir şekilde ifade edilmek üzere düzeltilmiştir.

\section{ANALIZ VE BULGULAR}

\section{Doğrulayıcı Faktör Analizleri}

Duygusal emeği oluşturan maddeler üzerinde doğrulayıcı faktör analizi yapılmış, üç ana faktör olan samimi, yüzeysel ve derin davranış (örtük değişken) ve 14 alt faktör (gözlenen değişken) analize sokulmuştur. Samimi davranışta yer alan iki madde (2 ve 7) analize sokulduğunda modelin uyum iyiliği indeksleri standart değerlerin altında yer almıştır.
Tablo 1. İş-Aile Çatışması ve Duygusal Emek Ölçeğine İlişkin Uyum İyiliği İstatistikleri

\begin{tabular}{|c|c|c|c|}
\hline $\begin{array}{l}\text { Uyum } \\
\text { İyiliği } \\
\text { Ölçütleri }\end{array}$ & $\begin{array}{c}\text { Duygusal Emek } \\
\text { Uyum-İyiliği } \\
\text { Değerleri }\end{array}$ & $\begin{array}{c}\text { İş-Aile Çatısması } \text { Uyum-Iyiliği } \\
\text { Değerleri }\end{array}$ & $\begin{array}{l}\text { Standart } \\
\text { Değerler }\end{array}$ \\
\hline $\begin{array}{l}\text { CMIN/DF } \\
(\chi 2 / d f)\end{array}$ & 2,945 & 2,779 & $\leq 3$ \\
\hline RMSEA & ,080 & ,077 & $\begin{array}{c}\leq, 08 \\
\text { veya, } 10\end{array}$ \\
\hline CFI & ,91 & ,97 & $\geq, 90$ \\
\hline GFI & ,91 & ,96 & $\geq, 90$ \\
\hline$A G F I$ & ,86 & ,91 & $\geq, 90$ \\
\hline
\end{tabular}

Bu maddeler analiz dışı bırakıldığında ise modelin uyum iyiliği indeksleri Tablo 1'de de görüldüğü gibi standart değerlere eşit veya bu değerlerden daha yüksek çıkmaktadır. Uyum iyiliği değerleri incelendiğinde, $\chi^{2} / \mathrm{df}=2,945^{\prime}$ nin 3 değerinden küçük olduğu, $C F I=, 91$ ve $G F I=, 91$ uyum iyiliği değerlerinin, 90'nın üzerinde olduğu görülmektedir. Bu değerler oluşturulan modelin uyumunun mükemmel olduğunu ifade ederken RMSEA'nın ,08 olması ve AGFI'nın ,86 olması modelin uyumun kabul edilebilir değerler içerisinde olduğunu göstermektedir (SchermellehEngel vd. 2003).

Daha sonra, iş-aile çatışması ölçeğindeki dokuz madde, üç boyutlu bir yapı olarak doğrulayıc faktör analizine tabi tutularak test edilmiştir. Tablo 1'de iş-aile çatışması maddelerinin doğrulayıcı faktör analizi sonrasında ortaya ç1kan uyum iyiliği değerleri incelendiğinde, $\chi^{2} / \mathrm{df}$ $=2,779^{\prime}$ nin 3 değerinden küçük olduğu, $\mathrm{CFI}=, 97$, GFI $=, 96$ ve $A G F I=, 91$ uyum iyiliği değerlerinin, 90'nın üzerinde olduğu görülmektedir. Bu değerler oluşturulan modelin uyumunun mükemmel olduğunu ifade ederken RMSEA'nın ,08 olması modelin uyumun kabul edilebilir değerler içerisinde olduğunu göstermektedir (Schermelleh-Engel vd. 2003: 52).

Duygusal emek değişkenini ölçen 14 madde ve üç faktör Şekil 1'de görülmektedir.

Şekil 2'de iş-aile çatışması ölçeğinin doğrulayıcı faktör analizi yapıldıktan sonra ortaya çıkan durum yer almaktadır. 


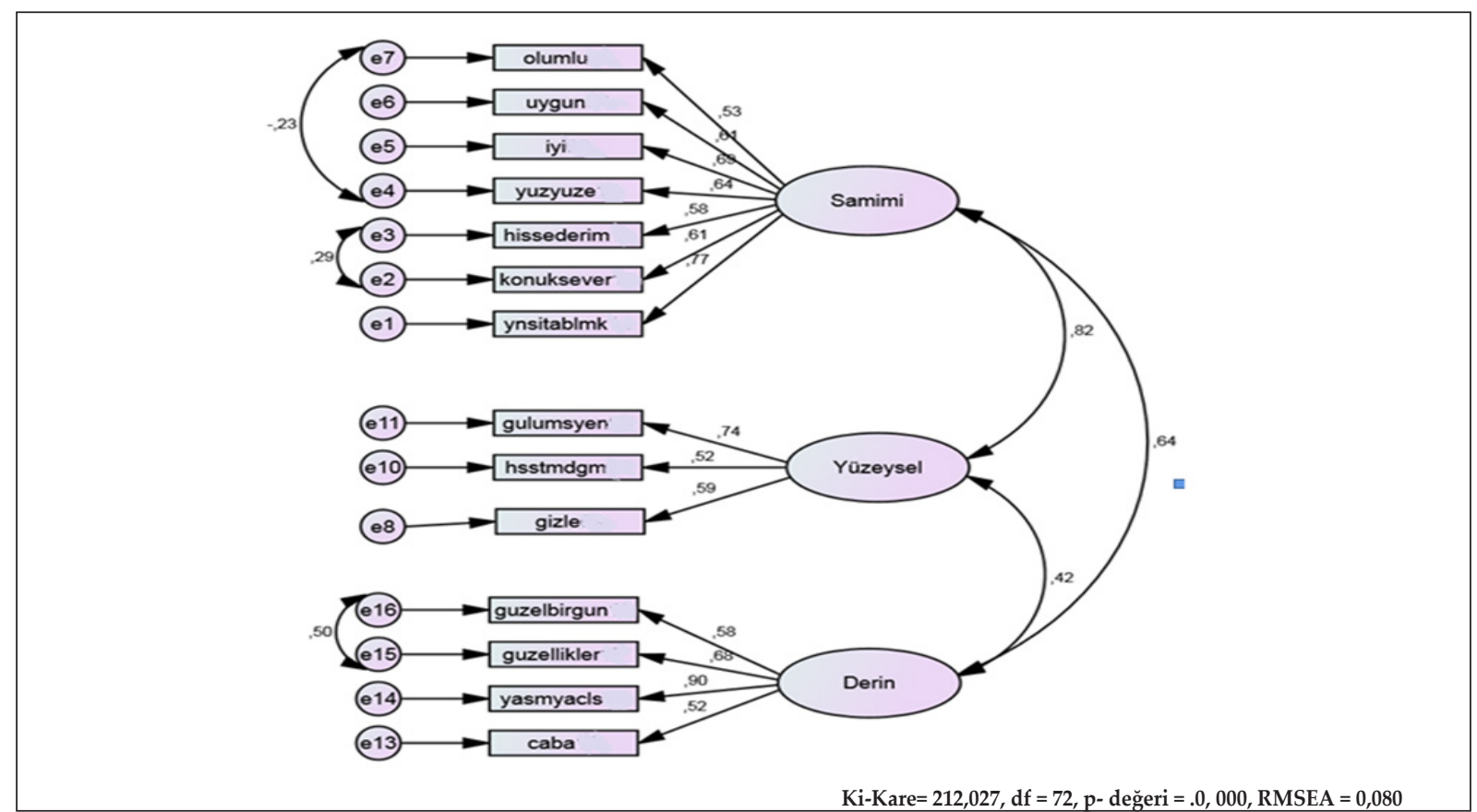

Şekil 1. Duygusal Emek Ölçeği Path Diyagramı

Değişkenlerin Tanımlayıcı İstatistikleri, Korelasyon ve Güvenirlik Değerleri

Bu çalışmada kullanılan alt ölçeklerin ortalama ve standart sapma değerleri, korelasyon katsayıları ile güvenilirlik analizleri sonucunda elde edilen Cronbach Alfa katsayıları Tablo 2'de verilmekte- dir. Duygusal emek boyutlarının ortalamaları incelendiğinde otel çalışanlarının belli düzeylerde duygusal emek davranışı gösterdikleri görülmektedir. İş-aile çatışması boyutları incelendiğinde ise nötr ve altında değerler olduğu ve iş-aile çatışmasının pek yaşanmadığı söylenebilir.

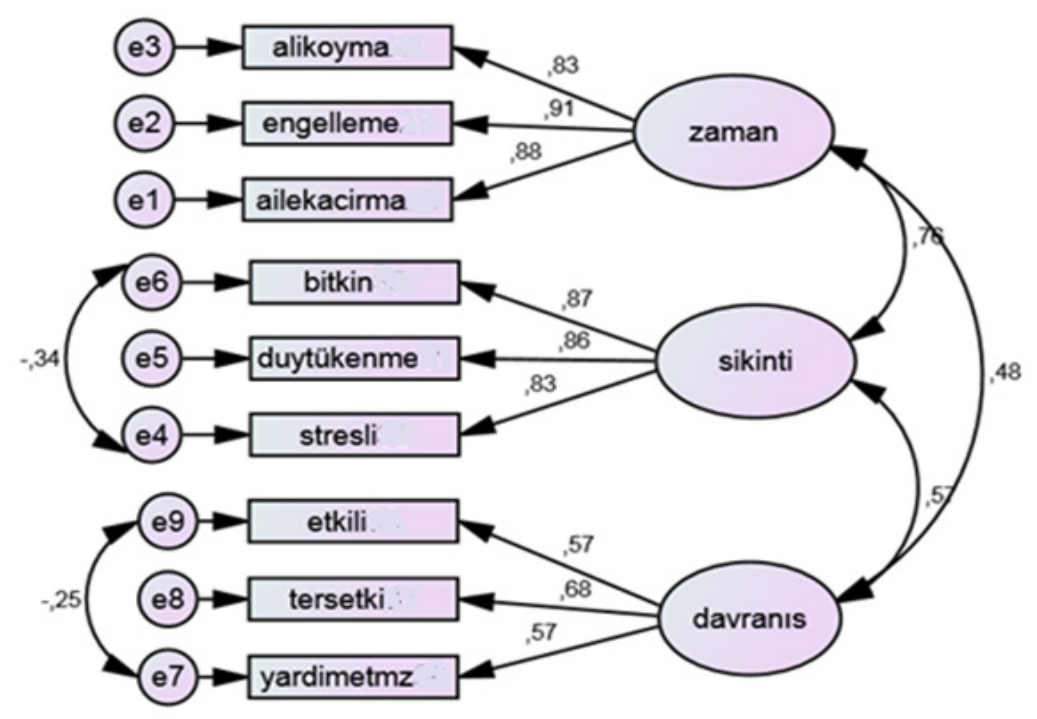

Ki-Kare $=212,027, \mathrm{df}=22, \mathrm{p}$-değeri $=0,000$, RMSEA $=0.077$

Şekil 2. İş-Aile Yaşam Çatışması Ölçeği Path Diyagramı 
Tablo 2. Değişkenlerin Tanımlayıcı İstatistikleri, Korelasyon ve Güvenirlik Değerleri

\begin{tabular}{|c|c|c|c|c|c|c|c|c|}
\hline & Ortalama & $\begin{array}{c}\text { Standart } \\
\text { Sapma }\end{array}$ & 1 & 2 & 3 & 4 & 5 & 6 \\
\hline 1.Samimi Davranış & 5,87 & ,88 & 825 & & & & & \\
\hline 2.Yüzeysel Davranış & 5,44 & 1,05 &, $57^{* *}$ & ,728 & & & & \\
\hline 3.Derin Davranış & 5,41 & 1,15 &, $51^{* *}$ &, $37^{* *}$ & 769 & & & \\
\hline 4. Zaman temelli iş-aile çatışması & 4,09 & 1,76 & $12^{*}$ & $15^{* *}$ & ,08 & 904 & & \\
\hline 5. Sıkıntı temelli iş-aile çatışması & 3,93 & 1,70 & 05 & ,10 & ,06 &, $71^{* *}$ & ,870 & \\
\hline 6. Davranış temelli iş-aile çatışması & 3,65 & 127, & 08 & $21^{* *}$ & $14^{*}$ & $38^{* *}$ & $46^{* *}$ & 670 \\
\hline
\end{tabular}

Not: 7'li Likert tipi değerlendirme ölçeği (1=hiç katılmıyorum; 4=nötrüm, 7=tamamen katılıyorum)

Korelasyonlar ${ }^{*} \mathrm{p}<, 05,{ }^{* *} \mathrm{p}<$,01düzeylerinde anlamlıdır.

Çaprazda koyu verilen değerler değişkenlerin iç tutarlılıklarını göstermektedir.

Duygusal emek boyutları arasinda korelasyon katsayıları incelendiğinde; Samimi davranış ile Yüzeysel davranış arasında $(\mathrm{r}=, 57, \mathrm{p}<, 01)$, Samimi davranış ile Derin davranış arasında $(\mathrm{r}=, 51$, $\mathrm{p}<, 01)$, Yüzeysel davranış ile Derin davranış arasinda $(\mathrm{r}=, 37, \mathrm{p}<, 01)$ pozitif ve orta düzeyde bir ilişki olduğu görülmektedir.

İş-aile çatışmanı boyutları arasındaki korelasyon katsayıları şu şekildedir: Zaman temelli işaile çatışması ile Sıkıntı temelli iş-aile çatışması arasında $(\mathrm{r}=, 71, \mathrm{p}<, 01)$ pozitif ve yüksek bir ilişki; Sıkıntı temelli iş-aile çatışması ile Davranış temelli iş-aile çatışması arasında $(r=46, p<, 01)$ ve Zaman temelli iş-aile çatışması ile Davranış temelli iş-aile çatışması arasında( $\mathrm{r}=, 38, \mathrm{p}<, 01)$ pozitif ve orta düzeyde bir ilişki olduğu görülmektedir.

Ölçeklerin güvenirlik analizleri incelendiğinde, samimi davranışın,825; yüzeysel davranışın ,728; derin davranışın,769; zaman temelli iş-aile çatış- masının ,904; sıkıntı temelli iş-aile çatışmasının ,870 ve davranış temelli iş-aile çatışmasının ,670 iç tutarlık katsayılarına sahip olarak güvenilir olduğu ortaya çıkmaktadır.

Yüzeysel davranış ile Zaman temelli iş-aile çatışması $(\mathrm{r}=, 15, \mathrm{p}<, 01)$ ve Davranış temelli iş-aile çatışması $(\mathrm{r}=, 21, \mathrm{p}<, 01)$ arasında pozitif düşük düzeyde ilişkiye rastlanmıştır. Bu sonuçlar doğrultusunda $\mathrm{H}_{1}$ 'in kısmen desteklendiği görülmektedir. Yüzeysel davranışın iş-aile çatışmasının üç boyutu ile pozitif ilişkili olduğu öngörülürken analiz sonucunda yüzeysel davranışın zaman temelli iş-aile çatışması ve davranış temelli iş-aile çatışması ile pozitif ilişkili olduğu ancak sıkıntı temelli iş-aile çatışması ile herhangi bir ilişkisinin olmadığı bulunmuştur.

Derin davranış ile yalnızca davranış temelli işaile çatışması $(\mathrm{r}=, 14, \mathrm{p}<, 05)$, arasında pozitif anlamlı bir ilişki bulunmuş, diğer iş-aile çatışması boyutlarıyla ilişki bulunmadığından $\mathrm{H}_{2}$ kısmen

Tablo 3. İ̧s- Aile Çatışması Regresyon Analizi

\begin{tabular}{|c|c|c|c|c|c|c|c|}
\hline $\begin{array}{c}\text { Bă̆ıml } \\
\text { Değişkenler }\end{array}$ & $\begin{array}{l}\text { Bă̆̆ımsız } \\
\text { Değişkenler }\end{array}$ & $\begin{array}{l}\text { Beta } \\
\text { değeri }\end{array}$ & $\stackrel{t}{t}$ & $\underset{\text { değeri }}{p}$ & $\begin{array}{l}\text { Düz. } R \\
\text { Kare }\end{array}$ & $F$ test $i$ & $\begin{array}{c}F \\
\text { anlamlilık }\end{array}$ \\
\hline $\begin{array}{l}\text { Zaman temelli } \\
\text { iş-aile çatışması }\end{array}$ & $\begin{array}{l}\text { Samimi davranış } \\
\text { Yüzeysel davranış } \\
\text { Derin davranış }\end{array}$ & $\begin{array}{l}, 057 \\
, 160 \\
, 037 \\
\end{array}$ & $\begin{array}{c}, 797 \\
2,725 \\
, 580\end{array}$ & $\begin{array}{l}, 426 \\
, 007 \\
, 562\end{array}$ & ,025 & 7,427 & 007 \\
\hline $\begin{array}{l}\text { Sıkıntı temelli } \\
\text { iş-aile çatışması }\end{array}$ & $\begin{array}{l}\text { Samimi davranış } \\
\text { Yüzeysel davranış } \\
\text { Derin davranış }\end{array}$ & $\begin{array}{l}-, 016 \\
, 096 \\
, 030\end{array}$ & $\begin{array}{c}-, 209 \\
1,329 \\
, 435\end{array}$ & $\begin{array}{l}834 \\
, 635 \\
, 664\end{array}$ & 010 & 970 & 407 \\
\hline $\begin{array}{l}\text { Davranış temelli } \\
\text { iş-aile çatışması }\end{array}$ & $\begin{array}{l}\text { Samimi davranış } \\
\text { Yüzeysel davranış } \\
\text { Derin davranış }\end{array}$ & $\begin{array}{l}-, 068 \\
, 215 \\
, 069\end{array}$ & $\begin{array}{l}-, 962 \\
3,702 \\
1,114\end{array}$ & $\begin{array}{l}337 \\
, 000 \\
, 266\end{array}$ & ,046 & 13,704 & ,000 \\
\hline
\end{tabular}


desteklenmiştir. Duygusal emek boyutlarından Samimi davranış ile Zaman temelli iş-aile çatışması arasında pozitif yönlü düşük düzeyde $(\mathrm{r}=$ $, 12, \mathrm{p}<, 05)$ bir ilişki saptanmıştır. Analiz sonuçlarında, samimi davranış ile davranış temelli iş-aile çatışması ve sıkıntı temelli iş-aile çatışması arasında bir ilişki bulunmadığından; samimi davranış ile zaman temelli iş-aile çatışması arasında negatif bir ilişkinin varlığ öngörülürken pozitif bir ilişki tespit edildiğinden $\mathrm{H}_{3}$ desteklenmemiştir. Otel çalışanlarının hizmet karşılaşmalarında gerçek duygularını sergiledikleri için iş-aile çatışması ile negatif ilişkili olduğu düşünülmüştür, ancak samimi davranış sergilediklerinde yaşadıkları zaman temelli iş-aile çatışmasının arttığı tespit edilmiştir.

\section{Regresyon Analizi}

Regresyon analizine göre, duygusal emek boyutları zaman temelli iş-aile çatışması ve davranış temelli iş-aile çatışmasını anlamlı olarak açıklamaktadır (Tablo 3). Duygusal emeğin zaman temelli iş-aile çatışmasının \%2,5'ini açıkladığı görülürken açıklamada etkili boyutun yüzeysel davranış (Beta $=, 160, p<, 01)$ olduğu ortaya çıkmıştır. Duygusal emek boyutlarının davranış temelli iş-aile çatışmasının \%4,6'sını açıkladığı ve etkili olan boyutun ise yine yüzeysel davranış $(B e t a=, 215, p<, 01)$ olduğu görülmektedir. $\mathrm{Bu}$ bulgular sonucunda duygusal emek boyutlarının sıkıntı temelli iş-aile çatışmasını anlamlı olarak açıklamadığ 1 için $\mathrm{H}_{4}$ 'ün kısmen desteklendiği söylenebilir.

\section{SONUÇ}

Bu çalışmada duygusal emek ile iş-aile çatışması arasındaki ilişkinin belirlenmesi amaçlanmıştır. Bu amacı gerçekleştirmek için İzmir şehir otellerinde 302 çalışandan anket yöntemiyle veri toplanmıştır. Duygusal emek ve iş-aile çatışması arasındaki ilişkiyi inceleyen araştırmalar son yıllarda artış gösterse de (Montgomery vd. 2005; 2006; Seery vd. 2008; Cheung ve Tang 2009; Yanchus vd. 2010) turizm ve otelcilik sektöründe bu ilişkiyi araştıran bir çalışmaya rastlanmamıştır. Bu nedenle çalışmada elde edilen bulgular alanyazına önemli katkılar sağlamaktadır.

\section{Bulgular ve Tartışma}

Duygusal emek değişkeninin doğrulayıcı faktör analizi sonucu ortaya çıkan üç boyutlu yapısı; yüzeysel, derin ve samimi davranış, Ashforth ve Humphrey'in (1993) kavramsallaştırdığ 1 ve Cheung ve Tang (2009), Diefenderff vd. (2005), Lee ve Ok (2012) ve Pala'nın (2008:50) çalışmalarındaki faktör yapısını desteklemektedir.

İş-aile çatışması değişkenini ölçen dokuz maddenin doğrulayıcı faktör analizi, Carlson vd. (2000) tarafından geliştirilen üç faktörlü yapıyı desteklemiş̧ir. İş-aile çatışması; zaman, sıkıntı ve davranış temelli olarak alanyazında kullanılan diğer ölçeklere göre (Netemeyer vd. 1996) daha kapsayıcı olarak çalışanların iş ve aile sorumluluklarının çatışmasını belirlemektedir (Seery vd. 2008). İş-aile çatışmasının üç boyutu iş-aile çatışmasının öncelleri ve çıktılarıyla farklı şekillerde ilişkili olduğundan tek bir değişken olarak değil de boyutlar bazında incelenmesi isabetli olmaktadır (Seery vd. 2008:474).

İş-aile çatışmasını tek boyut değişken olarak ölçen çalışmalarda (Montgomery vd.2005; 2006; Cheung ve Tang2009; Yanchus vd. 2010) yüzeysel davranış ile iş-aile çatışması arasında $(r=, 23$ ile $=, 28$ arasında; $\mathrm{p}<, 01$ ) pozitif ilişkiler bulunmuştur. Bu çalışmalarda derin davranış ile işaile çatışması arasında ise anlamlı bir ilişki bulunmamıştır. İş-aile çatışması ile duygusal emek arasındaki ilişkiyi inceleyen ve duygusal emek boyutlarından samimi davranışı da ölçen tek çalişmada (Cheung ve Tang2009) samimi davranış ile iş-aile çatışması arasında anlamlı bir ilişki bulunmamıştır.

İş-aile çatışmasını Carlson vd. (2000) ölçeğiyle üç boyutlu olarak operasyonel hale getiren Seery vd. (2008) çalışma bulgularıyla bu çalışmanın bulguları aşağıdaki şekilde karşılaştırılarak sunulmuştur. ABD'de 363 hemşire ve çocuk bakıcısından toplayan Seery vd. (2008) çalışmasına benzer şekilde, bu çalışmada da yüzeysel davranış ile zaman temelli iş-aile çatışması $(r=, 15$; $\mathrm{p}<, 05)$ ve davranış temelli iş-aile çatışması arasında $(\mathrm{r}=, 21 ; \mathrm{p}<, 01)$ pozitif ilişkiye rastlanmıştır. Seery vd. bu ilişkilerdeki korelasyon katsayısını sırasiyla $r=, 24$ ve $r=, 26(p<, 01)$ olarak bulmuştur. Otel çalışanlarıyla yapılan bu çalışmada yüzey- 
sel davranış ile sıkıntı temelli iş-aile çatışması arasında anlamlı bir ilişki bulunmamıştır. Seery vd. (2008) ise bu değişkenler arasında pozitif bir ilişki $(r=, 30 ; p<, 01)$ saptamıştır. Bu çalışmada derin davranış ile davranış temelli iş-aile çatışması arasında pozitif ilişki $(\mathrm{r}=, 14 ; \mathrm{p}<, 05)$ belirlenmişken, diğer iki iş-aile çatışması arasında anlamlı bir ilişki bulunmamıştır. Seery vd. (2008) ise derin davranış ile zaman temelli iş-aile çatışması arasında pozitif ilişki $(\mathrm{r}=, 11 ; \mathrm{p}<, 05)$ bulurken diğer iki iş-aile çatışması arasında anlamlı bir ilişki saptamamıştır. Bu çalışmada samimi davranış ile sadece zaman temelli iş-aile çatışması arasında düşük düzeyde pozitif ilişki $(r=, 12 ; p<, 05)$ bulunmuştur.

Duygusal emek boyutları zaman temelli iş-aile çatışması ve davranış temelli iş-aile çatışması üzerinde açıklayıcı olurken, yüzeysel davranış boyutu bu açıklamada etkili olmuştur. Seery vd. (2008) çalışmasında ise iş-aile çatışmasının üç boyutu da yine yüzeysel davranış boyutu tarafından açıklanmıştır. İş-aile çatışmasını tek boyut olarak ölçen çalışmalarda da yine yüzeysel davranış iş-aile çatışması üzerinde belirleyici olurken, derin davranış ve samimi davranış etkili olmamıştır (Montgomery vd.2005; Cheung ve Tang 2009).

\section{Teori ve Uygulamaya Katkı}

Çeşitli sektör çalışanlarıyla yapılan çalışmalarda iş-aile çatışması ile duygusal emek arasında ilişki incelense de (Montgomery vd.2005; 2006; Seery vd. 2008; Cheung ve Tang 2009; Yanchus vd. 2010) bu ilişkinin incelendiği turizm işletmeleri çalışanlarıyla yapılan herhangi bir çalışmaya rastlanmamıştır. Duygusal emek ve iş-aile çatışması ilişkisinin araştırıldığı hiçbir çalışmada, iki değişken de üçer boyutuyla operasyonel hale getirilmemiştir. Bu açılardan bu çalışma alanyazına orijinal katkılar sunmaktadır.

Çalışmadaki değişkenlerin kavramsallaştırılmasında ve ölçülmesinde kullanılan ölçeklerin farklılı̆̆ından dolayı alanyazındaki çalışmaların sonuçları birebir karşılaştırılamasa da öne çıkan unsur yüzeysel davranışın iş-aile çatışması üzerinde açıklayıcı olduğudur. Özellikle davranış temelli iş-aile çatışması üzerinde bu etki daha bariz olarak görülmektedir. Kaynakların Korunması Teorisi'nin de (Cheung ve Tang 2009) açıkladığı gibi çalışanların yüzeysel davranış göstermek için harcadığg enerji hem iş hem de aile rollerini yerine getirmek için gerekli olan enerjilerine tehdit oluşturmaktadır. Bununla birlikte ortaya çıkan stres de çalışanların iş ve aile rollerini dengelemelerine engel olarak iş-aile çatışması yaşamalarına yol açabilmektedir.

Derin ve samimi davranış boyutları da önceki çalışmalarda olduğu gibi bu çalışmada da iş-aile çatışması üzerinde açılayıcı etkiye sahip olmamiştır. Bu boyutlar genelde iş tatmini ve kişisel başarı değişkenleriyle olumlu yönde ilişkili (Grandey 2003) olduğundan çalışanın işyerinde olumlu duygular içerisinde bulunmasına katkı sağlamaktadır. Çalışanların derin davranış sergileyerek örgütün istediği duyguları kendi gerçek duygularını kurban etmeden yaşamaya çalışmaları hem evdeki hem de işyerindeki taleplerle başa çıkmak için var olan kaynaklarını korumalarını sağlamaktadır (Cheung ve Tang 2009). Benzer şekilde, samimi davranış gösteren çalışanların hizmet karşılaşmalarında duygularını sergilerken özerk olmaları iş-aile çatışması ile samimi davranışın ilişkili bulunmama sebebi olabilir.

Yüzeysel davranış, çalışanların enerjilerini alarak duygusal tükenme (Grandey 2003) ve iş-aile çatışması yaşaması gibi olumsuz çıktılara yol açmaktadır. İş yerinde sergilenen yüzeysel davranışın azaltılması ve çalışanlara derinden ve samimi davranış tekniklerini öğretme konusunda verilecek eğitimler çalışan açısından iş-aile çatışmasının azaltılmasını sağlayabilir. Öncelikle yöneticiler daha sonra çalışanlar için sağlanacak proaktif duygu yönetimi eğitimleri ve çalışanlar ve yöneticiler arasındaki iletişimin arttırılmasına olanak verecek sosyal ortamların yaratılması, yüzeysel davranışın seviyesinin azaltılmasına yardımcı olabilir. Çalışan seçim, eğitim, terfi ve ödüllendirme sistemleri üzerinde çalışarak müşteri istek ve ihtiyaçlarını anlayıp onlara güler yüzlü, arkadaşça ve nazik bir tutum ve davranış gösterecek çalışanlara sahip olmak iş-aile çatışmasını düşürerek çalışan mutluluğunu, müşteri memnuniyetini ve işletmelerin rekabet gücünü arttıracaktır. 


\section{KAYNAKÇA}

Allen, T.D. ve Finkelstein, L.M. (2014). Work-Family Conflict among Members of Full-Time Dual-Earner Couples: An Examination of Family Life Stage, Gender, and Age, Journal of Occupational Health Psychology,19 (3): 376-384.

Ashforth, B.E. ve Humphrey, R.H. (1993). Emotional Labor in Service Roles: Influence of Identity, Academy of Management Review, 18:88-115.

Byron, K. (2005). A Meta-Analytic Review of Work-Family Conflicts and Its Antecedents, Journal of Vocational Behaviour, 67:169-198.

Brislin, R.W.,Lonner, W.J. ve Thorndike, R.M. (1973). Cross Cultural Research Methods. New York: John Willey\&SonsPub.

Brotheridge, C.M. ve Lee, R.T. (2002). Testing a Conservation of Resources Model of the Dynamics of Emotional Labor, Journal of Occupational Health Psychology, 7: 57-67.

Carlson, D.S., Kacmar, K.M. ve Williams, L.J. (2000). Construction and Initial Validation of a Multi-dimensional Measure of Work-Family Conflict, Journal of Vocational Behavior, 56 (2): 249-276.

Cheung, F.Y. ve Tang, C.S. (2009). Quality of Work Life as a Mediator Between Emotional Labor and Work-Family Interference, Journal of Business and Psychology, 24: 245255.

Chu, K.H. ve Murrmann, S.K. (2006). Development and Validation of the Hospitality Emotional Labor Scale, Tourism Management, 27: 1181-1191.

Chu, K.H., Baker, M.A. ve Murrmann, S.K. (2012). When We are On Stage, We Smile: The effect of Emotional Labor on Employee Work Outcomes, International Journal of Hospitality Management, 31: 906-915.

Diefendorff, J.M., Croyle, M.H. ve Grosserand, R.H. (2005). The Dimensionality and Antecedents of Emotional Labor Strategies, Journal of Vocational Behaviour, 66: 339357.

Eby, L.T., Maher, C.P. ve Butts, M.M. (2010). The Intersection of Work and Family Life: The Role of Affect, Annual Review of Psychology, 61: 599-622.

Frone, M.R. (2003). Handbook of Occupational Health Psychology. İçinde Quick J.C. ve Tetrick L.E. (Editörler) Work-Family Balance (ss.143-162). Washington DC: American Psychological Association.

Grandey, A. (2000). Emotion Regulation in the Workplace: A New Way to Conceptualize Emotional Labor, Journal of Occupational Health Psychology, 5: 95-110.

Grandey, A.A. (2003). When The Show Must Go on: Surface Acting and Deep Acting as Determinants of Emotional Exhaustion and Peer-Rated Service Delivery, Academy of Management Journal, 46: 86-96.

Greenhaus, J. H. Ve Beutell, N. J. (1985). Source of Conflict Between Work and Family Roles, Academy of Management Review, 10 (1): 76-88.

Hochschild, A.R. (1983). The Managed Heart: The Commercialization of Human Feeling. Berkeley: University of California Press.
İzmir İl Kültür ve Turizm Müdürlüğü, http://www.izmirturizm.gov.tr/TR,77217/konaklama-verileri.html, Erişim tarihi: 5 Şubat 2014.

Karatepe, O.M., Sökmen, A., Yavaş, U. ve Babakuş, E. (2010). Work-Family Conflict and Burnout in Frontline Service Jobs: Direct, Mediating and Moderating Effects, Ekonomika A Management, 4: 61-73.

Kruml, S.M. ve Geddes, D. (2000). Exploring the Dimensions of Emotional Labor: Hochschild's Work, Management Communication Quarterly, 14: 8-49.

Lee, J. J. ve Ok, C. (2012).Reducing Burnout and Enhancing Job Satisfaction: Critical Role of Hotel Employees' Emotional Intelligence and Emotional Labor, International Journal of Hospitality Management, 31: 1101-1112.

Lee, J. J. ve Ok, C. (2015). Examination of Factors Affecting Hotel Employees' Service Orientation: An Emotional Labor Perspective, Journal of Hospitality and TourismResearch, 39 (4): 437-468.

Magnini, V.P. (2009). Understanding and Reducing WorkFamily Conflict in the Hospitality Industry, Journal of Human Resources in HospitalityETourism, 8:119-136.

Montgomery, A. J.,Panagopoulou, E. ve Benos, A. (2005). Emotional Labor at Work and at Home among Greek Health Care Professionals, Journal of Health Organization and Management, 19: 395-408.

Montgomery, A. J., Panagopolou, E. Wildt, M. ve Meenks, E. (2006). Work-Family Interference Emotional Labor and Burnout, Journal of Managerial Psychology, 21: 36-51.

Morris, J.A. ve Feldman, D.C. (1996). The Dimensions, Antecedents and Consequences of Emotional Labor, Academy of Management Review, 21 (4): 906-1010.

Netemeyer, R. G.,Bole, J. S. ve McMurrian, R. (1996). Development and Validation of Work-Family Conflict and Family-Work Conflict Scales, Journal of Applied Psycho$\log y, 81(4): 400-410$.

Pala, T. ve Tepeci, M. (2009). Turizm İşletmelerinde Çalışanların Duygusal Emek Düzeyi ve Duygusal Emeğin Çalışanların Tutumlarına Etkileri. 17. Ulusal Yönetim ve Organizasyon Kongresi, Eskişehir Osmangazi Üniversitesi, 21-23 May1s, 113-119.

Pala, T. ve Tepeci, M. (2014). Otel İşletmelerinde Çalışanların Duygusal Emek Boyutlarının Belirlenmesi ve Duygusal Emek Boyutlarının İş Tatmini ve İşte Kalma Niyeti Üzerine Etkisi, Seyahat ve Otel İ̧sletmeciliği Dergisi, 11(1): 21-37.

Schermelleh-Engel, K., Moosbrugger, H. ve Müller, H. (2003). Evaluating the Fit of Structural Equation Models: Tests of Signifigance andDescriptive Goodness-of-Fit Measures, Methods of Psychological Research Online, 8 (2): 23-74.

Seery, B. L., Corrigall, E. A. ve Harpel, T. (2008). Job-Related Emotional Labor and Its Relationship to Work-Family Conflict and Facilitation, Journal Family and Economic Issues, 29: 461-477.

Selvarajan, T.T., Singh, B., ve Cloninger, P.A. (2016). Role of Personality and Affect on the Social Support and Work Family Conflict Relationship, Journal of Vocational Behavior, 94: 39-56. 
Voydanoff, P. (2004). Implication of Work and Community Demand and Resources for Work-to-Family Conflict and Facilitation, Journal of Occupational Health Psycho$\log y, 9$ (4): 275-285.

Wharton, A. S.ve Erickson, R. J. (1993).Managing Emotions on the Job and at Home: Understanding the Consequences of the Multiple Emotional Roles, Academy of Management Review, 18 (3): 457-495.

Yanchus, N. J., Eby, L. T., Lance, C. E. ve Drollinger, S. (2010). The Impact of Emotional Labor on Work-Family Outcomes, Journal of Vocational Behaviour, 76: 105-117.
Yavaş, U., Babakuş, E. ve Karatepe, O.M. (2008).Attitudinal and Behavioral Consequences of the Work-Family Conflict and Family-Work Conflict: Does Gender Matter? International Journal of Service Industry Management, 19 (1): 7-31.

Yazıcıoğlu, Y. ve Erdoğan, S. (2004). SPSS Uygulamalı Bilimsel Araştırma Yöntemleri. Ankara: Detay Yayıncılık.

Zhao, X., Qu, H. ve Liu, J. (2014). An Investigation into the Relationship Between Hospitality Employees' WorkFamily Conflict and Their Leisure Intentions, Cornell Hospitaliy Quarterly, 55 (4): 408-421.

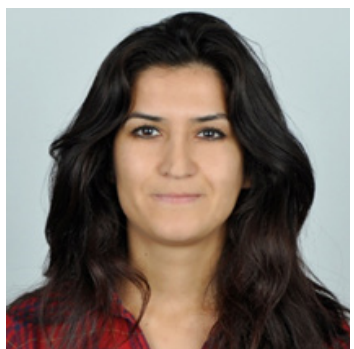

\section{Tuğba PALA}

Çukurova Üniversitesi İktisadi İdari Bilimler Fakültesi İktisat bölümünden mezun oldu (2004). Yüksek lisans derecesini Mersin Üniversitesi'nden Turizm İşletmeciliği ve Otelcilik dalından (2008), doktora derecesini de Dokuz Eylül Üniversitesi'nden Turizm İşletmeciliği dalından aldı (2014). Mersin Üniversitesi'nde Araştırma Görevlisi olarak çalışmaya başladı (2007-2008). Daha sonra 35. madde ile Dokuz Eylül Üniversitesi'nde Araştırma Görevlisi olarak çalıştı (2008-2015). Halen Mersin Üniversitesi Turizm Fakültesi'nde Araş. Gör. Dr. olarak görev yapmaktadır. Temel çalışma alanları duygusal emek, iş-aile çatışmasıdır.

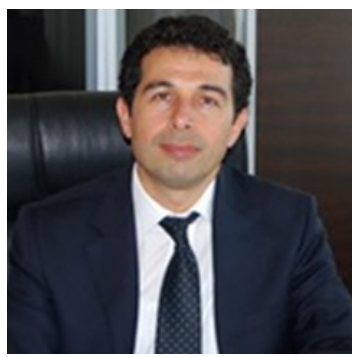

\section{Mustafa TEPECI}

Uludağ Üniversitesi Balıkesir Turizm İşletmeciliği ve Otelcilik Yüksekokulu'ndan mezun oldu (1991). Yüksek lisans derecesini ABD'de New Haven (CT) Üniversitesi'nden Turizm İşletmeciliği alanından (1996), doktora derecesini de ABD'de PennState Üniversitesi'nden (PA) Turizm İşletmeciliği alanından aldı (2001). Haziran 2001'de yurda döndükten sonra Mersin Üniversitesi Turizm İşletmeciliği ve Otelcilik Yüksekokulu'nda çalışmaya başladı. Mersin Üniversitesi'nde 2002 yılında Yrd.Doç., 2005-2008 yıllarında ise Doçent unvanıyla çalıştıktan sonra Haziran 2008 tarihinde Celal Bayar Üniversitesi Uygulamalı Bilimler Yüksekokuluna Doçent olarak atandı. Doçentlik unvanını Yönetim ve Organizasyon alanında aldı (2005). Profesörlüğe Celal Bayar Üniversitesi'nde yükseltildi (2011). Halen Celal Bayar Üniversitesi İşletme Fakültesi'nde Turizm İşletmeciliği Bölüm Başkanı olarak görev yapmaktadır. Temel çalışma alanları; stratejik yönetim, yenilikçilik, girişimcilik, kişi-örgüt uyumu, duygusal emek, yönetici yetkinlikleri ve ekip çalışmasıdır.

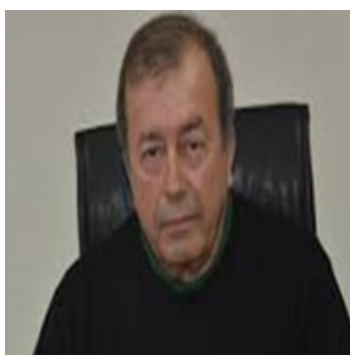

\section{Alp TIMUUR}

Ege Üniversitesi İktisadi ve Ticari Bilimler Fakültesi, Sanayi ve Ticaret İşletmeciliği Bölümü'nden mezun oldu (1970). Yüksek lisans derecesini Ege Üniversitesi'nden İktisat dalından (1974), doktora derecesini de Ege Üniversitesi'nden Turizm İşletmeciliği dalından aldı (1978). Ege Üniversitesi İktisadi ve Ticari Bilimler Fakültesi'nde çalışmaya başladı (1971). Doçentlik unvanını Turizm İşletmeciliği alanında aldı (1983). Profesörlüğe Dokuz Eylül Üniversitesi'nde yükseltildi (1989). Dokuz Eylül Üniversitesi İktisadi ve İdari Bilimler Fakültesi'nden emekli oldu. (2016) Temel çalışma alanları turizm ekonomisi ve politikası, iktisat politikasıdır. 